\title{
Electrochemical degradation of Reactive Blue 19 dye by combining boron doped diamond and reticulated vitreous carbon electrodes
}

\author{
Vanessa M. Vasconcelos ${ }^{*}$, a , Carlos Ponce-de-León ${ }^{*}$, , , Stefan M. Rosiwalc, Marcos R.V. \\ Lanza ${ }^{*}$ a
}

anstituto de Química de São Carlos, Universidade de São Paulo, 13563-120, São Carlos, SP, Brazil.

\begin{abstract}
${ }^{\mathrm{b}}$ Faculty of Engineering and the Environment, University of Southampton, SO17 1BJ, Highfield, Southampton, England.

${ }^{c}$ University of Erlangen-Nuernberg, Martensstraße 5, 91058 Erlangen, Germany
\end{abstract}

* Corresponding author. Tel.: + 551633738659.

*E-mail address: marcoslanza@iqsc.usp.br (M.R.V. Lanza),

*E-mail address: vanessa.moura.vasconcelos@gmail.com (V.M. Vasconcelos),

*E-mail address: capla@soton.ac.uk (C. Ponce-de-León). 


\section{Graphical Abstract}

MECHANISM OF RB-19 ELECTROCHEMICAL DEGRADATION IN FILTER-PRESS FLOW REACTOR OF TWO COMPARTMENT FITTED WITH BDD AND RVC ELECTRODES

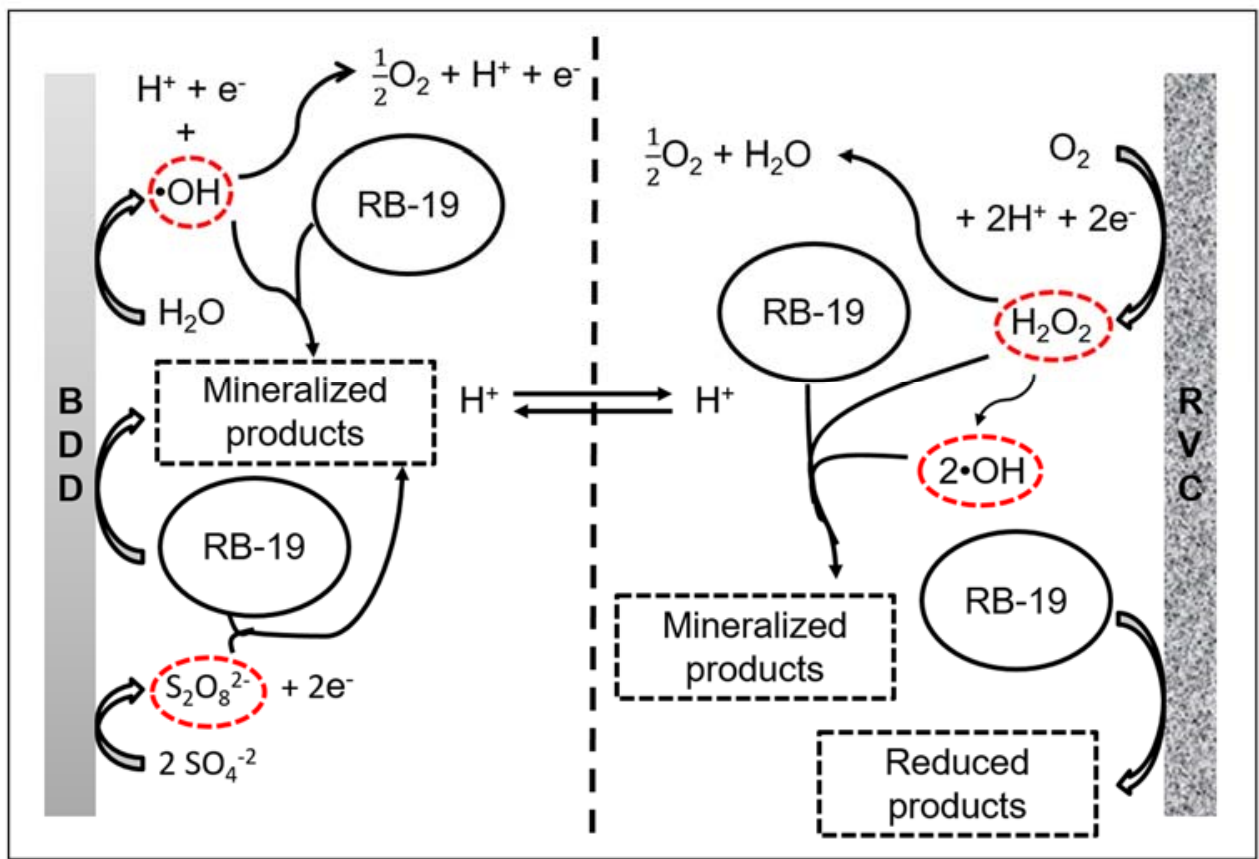




\section{Highlights}

- Removal of reactive blue 19 (RB-19) with combined BDD and RVC electrodes

- Total colour and mineralization of RB-19 by oxidation using BDD/Nb anodes

- The volumetric flow rate plays an important role of oxidation of $\mathrm{RB}-19$ using $\mathrm{BDD} / \mathrm{Nb}$

- The combination of BDD/Nb and RVC did not improve the RB-19 degradation 


\begin{abstract}
Reactive Blue 19 (RB-19) dye has low fixation efficiency, a long half-life and high toxicity. It is easily loss during the cleaning of textiles and can remain in the environment for long time causing serious environmental problems if not removed. This study reports the degradation of RB-19 by: 1) the electrochemical direct degradation with Boron-Doped Diamond (BDD) electrodes and 2) a combined processes using BDD and Reticulated Vitreous Carbon (RVC) electrodes that generates $\mathrm{H}_{2} \mathrm{O}_{2}$. The direct degradation uses different current densities and concentrations. High currents densities, longer electrolysis time and low volumetric flow rates, favour RB-19 degradation removing total colour and $100 \%$ TOC at 5 and 60 min respectively. At $41 \mathrm{~mA} \mathrm{~cm}{ }^{-2}$ current density and $20 \mathrm{dm}^{3} \mathrm{~h}^{-1}$ volumetric flow rate, the energy consumption to degrade $20 \mathrm{mg} \mathrm{dm}^{-3}$ of RB-19 was $279 \mathrm{kWh} \mathrm{kg}^{-1}$. The TOC removal of RB-19 dye combining $\mathrm{BDD}$ and $\mathrm{RVC}$ at a current density of $41 \mathrm{~mA} \mathrm{~cm}^{-2}$ was below $72 \%$ during $90 \mathrm{~min}$ and the energy consumption increased to $612 \mathrm{kWh} \mathrm{kg}^{-1}$. The higher energy consumption obtained during the combined process suggested that the direct degradation process at low volumetric flow rates is more efficient than the combined process.
\end{abstract}

Keywords: boron- doped diamond; electrochemical oxidation; filter-press flow reactor; $\mathrm{H}_{2} \mathrm{O}_{2}$ electrogeneration; reactive blue 19 dye; reticulated vitreous carbon. 


\section{Table of Contents}

1. Introduction

2. Experimental details

3. Results and discussion

3.1 Direct degradation of RB-19 dye

3.2 Degradation of RB-19 dye by combined processes

4. Conclusions

5. Acknowledgements

6. References 


\section{Introduction}

Anthraquinone-based, Reactive Blue 19 (RB-19) dye, is one of the most useful dyes in the textile industry due to its bright blue colour and resistant to light degradation. However, it has a low fixation efficiency on cellulose $(75-80 \%)$ because the covalent bonds that attach to the fibres, can be hydrolysed generating the 2-hydroxyethyl-sulfone which does not form links with the fibres and can easily release into the wastewater. ${ }^{[1]}$ An additional factor is that the halflife of the dye is around 46 years at $\mathrm{pH} 7$ and $25^{\circ} \mathrm{C} .{ }^{[2]}$ The $\mathrm{RB}-19$ dye is considered toxic with $75 \%>\mathrm{EC}_{20}>50 \%$ against Vibrio fischeri bioluminescent bacteria; $\mathrm{EC}_{20}$ is the percentage concentration of compound necessary to reduce in $20 \%$ the bioluminescence of Vibrio fischeri bacteria. ${ }^{[3]}$ The presence of RB-19 dye represents a serious environmental problem. ${ }^{[4]}$

Traditional municipal sewerage systems are designed to treat domestic water and are not suited to deal with organic dyes that have been detached from washing textiles at homes. Most domestic wastewaters present change of coloration due to the presence of these dyes but the technology is not able to remove organic synthetic dyes due to their complex structures, especially reactive dyes, which pass through the treatment unchanged. ${ }^{[5]}$ The degradation of anthraquinone-based dyes is even more difficult because they contain stable aromatic rings in their structure. ${ }^{[6]}$ Therefore, it is important to study an effective and low cost method to degrade these compounds before they are released into the environment ${ }^{[3]}$. Electrochemical techniques offer several advantages such as versatility, cost-effective, automation, environmental compatibility and specially, colour removal and total degradation. ${ }^{[5 c, 6-7]}$

In the direct electrochemical processes for organic removal, the electron transfer occurs between the pollutant and the electrode surface or with oxidizing species generated and adsorbed in the surface. In the indirect oxidation, the degradation occurs in the bulk of the 
solution by oxidizing species generated at the electrode such as hydrogen peroxide, which is a strong oxidant species with an oxidation potential of $E^{0}=1.80 \mathrm{~V}$ vs. SHE. ${ }^{[8]}$

Reticulated Vitreous Carbon (RVC) has been used routinely in electrochemical process that take advantage of its large surface area due to its honeycomb porous structure with large void volume. RVC has low resistance to fluid flow and high electrical and thermal conductivities, low density and thermal expansion, high corrosion resistance and a rigid structure ${ }^{[9]}$ suitable for $\mathrm{H}_{2} \mathrm{O}_{2}$ production in indirect electrochemical degradation of organics. ${ }^{[9 \mathrm{~b}]}$

Hydrogen peroxide can be continuously electrogenerated at the surface of the electrode by the reduction oxygen via two electrons (reaction 1), follow by further 2-electron reduction to $\mathrm{H}_{2} \mathrm{O}$, reaction 2. Oxygen can also be reduced directly to water via four electrons reaction 3 , these process can occur simultaneously. ${ }^{[10]}$ When the process is carried out in an undivided cell, $\mathrm{H}_{2} \mathrm{O}_{2}$ can also be oxidized at the anode surface, reactions 4 and 5. ${ }^{[11]}$ Hydrogen peroxide can generate hydroxyl radicals $(\cdot \mathrm{OH})$, reaction 6 , with higher oxidizing potential of $E^{0}=2.80 \mathrm{~V} v \mathrm{~s}$. SHE ${ }^{[12]}$ than $\mathrm{H}_{2} \mathrm{O}_{2}$, able to promote the mineralization of recalcitrant organic compounds.

$$
\begin{aligned}
\mathrm{O}_{2}(\mathrm{~g})+2 \mathrm{H}^{+}+2 \mathrm{e}^{-} \rightarrow \mathrm{H}_{2} \mathrm{O}_{2} & E^{\mathrm{o}}=0.695 \text { vs. SHE } \\
\mathrm{H}_{2} \mathrm{O}_{2}+2 \mathrm{H}^{+}+2 \mathrm{e}^{-} \rightarrow 2 \mathrm{H}_{2} \mathrm{O} & E^{\mathrm{o}}=1.776 \text { vs. SHE } \\
\mathrm{O}_{2}(\mathrm{~g})+4 \mathrm{H}^{+}+4 \mathrm{e}^{-} \rightarrow 2 \mathrm{H}_{2} \mathrm{O} & E^{\mathrm{o}}=1.23 \text { vs. SHE } \\
\mathrm{H}_{2} \mathrm{O}_{2} \rightarrow \mathrm{HO}_{2}^{\cdot}+\mathrm{H}^{+}+\mathrm{e}^{-} & E^{\mathrm{o}}=1.44 \text { vs. SHE } \\
\mathrm{HO}_{2} \cdot \rightarrow \mathrm{O}_{2}(\mathrm{~g})+\mathrm{H}^{+}+\mathrm{e}^{-} & \\
\mathrm{H}_{2} \mathrm{O}_{2} \rightarrow 2 \cdot \mathrm{OH} &
\end{aligned}
$$

The efficiency of the degradation of organic compounds depends on the electrode material. ${ }^{[\mathrm{c},}{ }^{8 \mathrm{~d}]}$ In the direct electrochemical treatment, the Boron Doped Diamond (BDD) 
electrodes are by far the best anode materials. ${ }^{[13]}$ Its electrochemical properties are unique, i.e. low capacitance, weak adsorption properties, low background current, high stability and high overvoltage for the oxygen and hydrogen evolution reactions, which favour the generation of - $\mathrm{OH}$ radicals promoting mineralization of organic compounds (reactions 7,8 and 9) instead of the oxygen evolution reaction. ${ }^{[14]}$ Electrolyses in medium of sulfate with BDD anodes generate highly oxidizing species such as persulfate anion before $\bullet \mathrm{OH}$, reactions 10 and $11 .^{[15]}$

$$
\begin{array}{ll}
\mathrm{BDD}+\mathrm{H}_{2} \mathrm{O} \rightarrow \mathrm{BDD}(\cdot \mathrm{OH})+\mathrm{H}^{+}+\mathrm{e}^{-} & \\
\mathrm{BDD}(\cdot \mathrm{OH})+\text { organic compounds } \rightarrow \mathrm{BDD}+\text { oxidized products }+\mathrm{H}^{+}+\mathrm{e}^{-} \\
\mathrm{DDB}(\cdot \mathrm{OH}) \rightarrow \mathrm{DDB}+1 / 2 \mathrm{O}_{2}+\mathrm{H}^{+}+\mathrm{e}^{-} & E^{\mathrm{o}}=2.01 \text { vs. SHE } \\
2 \mathrm{SO}_{2}^{4-} \rightarrow \mathrm{S}_{2} \mathrm{O}_{8}{ }^{2-}+2 \mathrm{e}^{-} & E^{\mathrm{o}}=2.123 \mathrm{~V} \text { vs. SHE } \\
2 \mathrm{HSO}^{4-} \rightarrow \mathrm{S}_{2} \mathrm{O}_{8}{ }^{2-}+2 \mathrm{H}^{+}+2 \mathrm{e}^{-} &
\end{array}
$$

Siddique et al. ${ }^{[16]}$ investigated several processes to treat RB-19 dye but there are only few works that have reported the use of BDD electrode for this dye. Montanaro and Petrucci ${ }^{[17]}$ for example used a $5 \mathrm{~cm}^{2}$ geometrical area BDD electrode in a single cell compartment to completely remove colour and TOC. They reported faster decolourisation in acidic $\mathrm{pH}$ and that the increase in temperature had a negative effect in the colour removal while it was beneficial for TOC removal. The degradation efficiency depended on the initial concentration of the dye. Petrucci and Montanaro ${ }^{[18]}$ also evaluated the degradation of $50 \mathrm{mg} \mathrm{dm}^{-3}$ of RB-19 dye in synthetic wastewater containing $0.01 \mathrm{mg} \mathrm{dm}^{-3}$ of $\mathrm{Na}_{2} \mathrm{CO}_{3}+0.023 \mathrm{mg} \mathrm{dm}^{-3}$ of $\mathrm{Na}_{2} \mathrm{SO}_{4}+0.05$ $\mathrm{mg} \mathrm{dm}{ }^{-3}$ of $\mathrm{NaCl}+0.0125 \mathrm{mg} \mathrm{dm}^{-3}$ of $\mathrm{NaOH}$ on a BDD electrode of $5 \mathrm{~cm}^{2}$ area at $20{ }^{\circ} \mathrm{C}$. At these conditions, $100 \%$ of TOC was removed after $120 \mathrm{~min}$ of electrolysis at $600 \mathrm{~mA} \mathrm{~cm} \mathrm{c}^{-2}$ current density. On the other hand Degaki et al. ${ }^{[19]}$ also reported a low TOC removal (65\%) after oxidation of $500 \mathrm{mg} \mathrm{dm}^{-3}$ of RB-19 dye in $0.1 \mathrm{~mol} \mathrm{dm}^{-3}$ of $\mathrm{Na}_{2} \mathrm{SO}_{4}$ even in presence of 34 
$\times 10^{-3} \mathrm{~mol} \mathrm{dm}^{-3}$ of $\mathrm{NaCl}$ when a charge of around $8 \mathrm{~A} \mathrm{~h} \mathrm{dm}^{-3}$ was applied to $\mathrm{BDD} / \mathrm{Nb}$ (geometric area of $11 \mathrm{~cm}^{2}$ ) and AISI-304 stainless steel foils cathodes fitted in a one-compartment filterpress reactor. 98 and $90 \%$ of colour removal were achieved under $5.5 \mathrm{~A} \mathrm{~h} \mathrm{dm}^{-3}$ and $0.32 \mathrm{~A} \mathrm{~h}$ $\mathrm{dm}^{-3}$ in the absence or presence of chloride ions $\left(34 \times 10^{-3} \mathrm{~mol} \mathrm{dm}^{-3}\right.$ of $\left.\mathrm{NaCl}\right)$, respectively.

Andrade et al. ${ }^{[20]}$ studied the electroxidation of $25 \mathrm{mg} \mathrm{dm}{ }^{-3} \mathrm{RB}-19$ dye in a onecompartment filter-press electrochemical reactor fitted with $\mathrm{DBB} / \mathrm{Nb}$ (anode electrode) and nickel sheet (cathode electrode), when $50 \mathrm{~mA} \mathrm{~cm}^{-2}$ was applied, 90\% decolourisation was achieved after $10 \mathrm{~min}$ and $82 \%$ of TOC was removed in $2 \mathrm{~h}$. The electrolyte was $0.5 \mathrm{~mol} \mathrm{dm}$ of $\mathrm{Na}_{2} \mathrm{SO}_{4}$ at $25{ }^{\circ} \mathrm{C}$ and the volumetric flow rate was $2.4 \mathrm{dm}^{3} \mathrm{~h}^{-1}$. Vasconcelos et al. ${ }^{[21]}$ reported the RB-19 degradation using a highly non-commercial BDD/Ti $\left(4.15 \mathrm{~cm}^{2}\right.$ with $\mathrm{B} / \mathrm{C}$ ratio of $15,000 \mathrm{ppm}$, a doping boron level of around $10^{19} \mathrm{~cm}^{3}$ ) in a one compartment electrochemical cell and Pt as cathode electrode. Applying $100 \mathrm{~mA} \mathrm{~cm}^{-2}$, total colour removal was achieved in $40 \mathrm{~min}$ and $99 \%$ of TOC removal was attained in $8 \mathrm{~h}$ with significant decrease in toxicity against Vibrio fischeri bioluminescent bacteria. The identified by-products of RB-19 oxidation were amino-anthraquinone, tautomers keto-enolic, hydroquinone and benzoquinone, benzoic acid, phenol and acid aliphatic, such as oxalic acid.

Brito et al. ${ }^{[22]}$ compared the degradation efficiency of the RB-19 using the BDD and $\mathrm{Ru}_{0.3} \mathrm{Ti}_{0.7} \mathrm{O}_{2} / \mathrm{Ti}$ electrodes in presence of $\mathrm{NaCl}$. Both electrodes removed total colour however BDD electrode promoted higher TOC removal than $\mathrm{Ru}_{0.3} \mathrm{Ti}_{0.7} \mathrm{O}_{2} / \mathrm{Ti}$ due to effective production of oxidant species such as $\bullet \mathrm{OH}, \mathrm{HClO}$ and $\mathrm{ClO}^{-}$that favour the degradation of organic matter. Farinos and Ruotolo ${ }^{[23]}$ compared the electrooxidation performance of three-dimensional $\mathrm{RVC} / \mathrm{PbO}_{2}$ and boron-doped diamond electrodes, which were used as anode and in separate compartments. The electrodes had similar current efficiency and energy consumption for the 
degradation of phenol and glyphosate due to the synergistic effects of increased surface area and mass transfer. The three-dimensional $\mathrm{RVC} / \mathrm{PbO}_{2}$ is an optional inexpensive electrode for the degradation of organic compounds.

As shown above, there are only a few papers reporting the electrochemical oxidation of RB-19 dye using BDD electrodes. In addition, only cells or reactors with one compartment were described and the combination of RVC and BDD fitted at a filter-press flow reactor to degrade RB-19 has not been reported in the literature. In this context, the aim of this paper is to degrade RB-19 dye by direct electrochemical method using BDD and the combination of direct and indirect electrochemical methods using BDD and RVC electrodes in a filter-press flow reactor with two divided compartments and compare their performance.

\section{Experimental details}

The degradation of RB-19 dye (50\% purity) from Sigma-Aldrich was studied using a filter-press flow reactor $(15 \times 9.0 \times 2.6 \mathrm{~cm})$ fitted with a 60 ppi Reticulated Vitreous Carbon (RVC) cathode and a Boron-Doped Diamond supported on niobium anode. The BDD electrode had a geometrical area of $27 \mathrm{~cm}^{2}$ exposed to the electrolyte and a doping boron level of 1,000$5,000 \mathrm{ppm}$ whereas the RVC had a superficial area around $1,540 \mathrm{~cm}^{2[9 \mathrm{a}]}$. The two compartments in the filter-press flow reactor were divided by a 115 Nafion $^{\circledR}$ membrane. Before the experiments, the membrane was treated with boiling water for $30 \mathrm{~min}$ and kept for $24 \mathrm{~h}$ in 1 mol dm ${ }^{-3} \mathrm{H}_{2} \mathrm{SO}_{4}$ Analar grade from Fisher Scientific. The filter-press flow reactor ${ }^{[24]}$ was connected to two reservoirs of $1.0 \mathrm{dm}^{-3}$ capacity and connected to two magnetically driven centrifugal pumps TE-3K-MD (March May). Two flowmeters were used to measure the volumetric flow rate of the catholyte and the anolyte independently; the electrochemical system 
was connected to an Autolab potentiostat (PGSTAT $302 \mathrm{~N}$ ) computer controlled with a GPS software.

Fig. 1a shows a schematic diagram of the direct degradation method. The configuration consist on two reservoirs, each one contain $500 \mathrm{~cm}^{3}$ aqueous solution of $\mathrm{Na}_{2} \mathrm{SO}_{4} 0.5 \mathrm{~mol} \mathrm{dm}^{-3}$ Analar grade from Fisher Scientific at $23{ }^{\circ} \mathrm{C}$, only the anolyte reservoir contained the dye, the anode and cathode flows were independent pumped through the electrochemical reactor. In the combined process shown in Fig 1b, the configuration consisted on one reservoir containing 500 $\mathrm{cm}^{3}$ aqueous solution of $\mathrm{Na}_{2} \mathrm{SO}_{4}$ electrolyte. The solution circulated through the cathodic compartment and then the solution was directed to the anodic compartment. More details of filter-press flow reactor can be find in Friedrich et al. ${ }^{[25]}$.

The electrochemical oxidation of RB-19 dye via the direct degradation process was carried out at different current densities $\left(4,8,21\right.$ and $\left.41 \mathrm{~mA} \mathrm{~cm}^{-2}\right)$, and different anode volumetric flow rates $\left(20,40,60,80\right.$ and $\left.100 \mathrm{dm}^{3} \mathrm{~h}^{-1}\right)$ and initial concentrations of 20, 90 and $410 \mathrm{mg} \mathrm{dm}{ }^{-3}$. The cathode flow was kept at $100 \mathrm{dm}^{3} \mathrm{~h}^{-1}$. In the combined degradation process, the current densities were, 4, 8, 21 and $41 \mathrm{~mA} \mathrm{~cm}^{-2}$ at flow rate of $100 \mathrm{dm}^{3} \mathrm{~h}^{-1}$ and the initial concentration of RB-19 dye was $20 \mathrm{mg} \mathrm{dm}^{-3}$. In this process the BDD electrode was used as the anode working electrode while the counter electrode was RVC. In previous study we quantified the amount of $\mathrm{H}_{2} \mathrm{O}_{2}$ generation from the reduction of dissolved oxygen which was constantly bubbled in the electrolyte ${ }^{[26]}$.

The degradations efficiency was evaluated using a UV-VIS spectrophotometer from Scinco (NEOSYS-2000) in the range of 200 to $800 \mathrm{~nm}$, begin the area in the visible (400-700 $\mathrm{nm})$ part of spectra used to calculate colour removal promoted through equation (12). The 
concentration of RB-19 was monitored during the electrochemical degradation assays using the calibration curve at $593 \mathrm{~nm}$. The mineralization efficiency was also evaluated using the TOC values obtained from a Shimadzu TOC-V $\mathrm{V}_{\mathrm{CPH}}$ analyser. The Energy Consumption (EC) calculated using equations (13) and (14), respectively ${ }^{[7 b, 8 b]}$ :

$$
\begin{aligned}
& \text { Color removal }(\%)=\left[\frac{\left(A_{0}-A_{t}\right)}{A_{0}}\right] \times 100 \\
& \text { TOC removal }=\left[\frac{\left(T C_{0}-T O C_{t}\right)}{T O C_{0}}\right] \times 100 \\
& E C\left(k W h k^{-1}\right)=\frac{1000 E I \Delta t}{\left(T O C_{0}-T O C_{t}\right) v}
\end{aligned}
$$

Where $A_{0}$ is the area under the curve of the spectrum from 400 to $700 \mathrm{~nm}$ before the electrolysis. $A_{t}$ is the area after a time $t$ of electrolysis, $T O C_{0}\left(\mathrm{mg} \mathrm{dm}^{-3}\right)$ is the total organic carbon before the electrolysis, $T O C_{t}$ is the total organic carbon after a time $t$ of electrolysis. $E C$ $\left(\mathrm{kWh} \mathrm{kg}^{-1}\right)$ is the energy consumption, $E(\mathrm{~V})$ is the average cell voltage, $I$ (A) is the applied current, $\Delta t(\mathrm{~h})$ the duration of electrolysis, and $v\left(\mathrm{dm}^{3}\right)$ is the volume of the electrolyte.

\section{Results and discussion}

\subsection{Direct degradation of RB-19 dye}

Figure 2 shows the percentage of colour removal at different current densities over 30 and 90 min of electrolysis. High current densities (Fig 2a) and longer electrolysis times (Fig 2b) improve colour removal since the concentration of electrogenerated hydroxyl radicals and persulfate anions increases and partially decompose the dye. High percentage of colour removal 
(>93\%) was achieved after 30 min of electrolysis at current density of $\geq 21 \mathrm{~mA} \mathrm{~cm}$ c $^{-2}$. Decolourisation of $>99 \%$ was also observed after 90 min of electrolysis at $>21 \mathrm{~mA} \mathrm{~cm}^{-2}$ current density.

This finding is very important since one of the issues concerning the treatment of textile wastewater is to remove the colour of very stable dyes that contain complex aromatic structures stabilized by the resonance mechanism like in the RB-19 molecule, Fig. 2b. ${ }^{[27]}$ The decolourisation is caused by the detachment of the anthraquinone group or by its reduction to antrahydroquinone, which is a colourless compound with higher molecular weight and aromatic groups. ${ }^{[28]}$ However, the reduction reaction of the dye is avoided by the use of a two separated compartments in the electrochemical flow cell.

Figure $2 \mathrm{~b}$ shows the absorption spectra of the solution containing the RB-19 dye as function of the electrolysis time. The characteristic UV bands of the dye are $(\lambda \approx 227,254$ and $290 \mathrm{~nm})$ and visible $(\lambda \approx 593 \mathrm{~nm})$. In the UV region, the most intense peak corresponds to the $227 \mathrm{~nm}$ wavelength, which is related to benzene rings; the absorption peaks at 254 and $290 \mathrm{~nm}$ wavelength are associated to the aromatic amines and naphthalene, respectively. The band in the visible region of spectrum $(\lambda \approx 593 \mathrm{~nm})$ is associated to the chromophoric group of RB-19 molecule, anthraquinone group. The absorption bands in UV region are due to $\pi-\pi^{*}$ transitions typical of unsaturated compounds. ${ }^{[29]}$ The curves in the figure shows that the intensity of the absorbance bands, gradually decreased as a function of electrolysis time and disappeared in the visible region of the spectra faster than in the UV region. This finding shows that it is easier to remove the colour of the dye than the absorbance of the compounds containing unsaturated bonds. At a current density of $41 \mathrm{~mA} \mathrm{~cm}^{-2}$ on the BDD electrode, the visible region of spectra 
disappeared at $7.5 \mathrm{~min}$ of electrolysis. In contrast, to remove completely the absorbance in the UV part of spectra required longer electrolysis time $(60 \mathrm{~min})$ at a volumetric flow rate of 100 $\mathrm{dm}^{3} \mathrm{~h}^{-1}$.

Figure 3a shows the effect of different current densities on the normalised concentration decay as a function of time at a volumetric flow rate of the anolyte of $100 \mathrm{dm}^{3} \mathrm{~h}^{-1}$ and initial concentration of $20 \mathrm{mg} \mathrm{dm}^{-3}$. At a current density of $21 \mathrm{~mA} \mathrm{~cm}^{-2}$ applied to the BDD electrode, the RB-19 dye was totally removed in 30 minutes. Increasing the current density twice to 41 $\mathrm{mA} \mathrm{cm}{ }^{-2}$, the dye was completely removed faster, in 7.5 minutes. At current densities $\leq 21 \mathrm{~mA}$ $\mathrm{cm}^{-2}$ the dye was not removed completely even after 90 minutes of electrolysis. Furthermore, it is possible to see a linear relationship between the normalized concentration decay of the RB19 dye and the electrolysis time for all current densities studied. This behaviour suggests, RB19 removal reaction followed a pseudo zero order kinetic model and the degradation regime seems to be electron transfer controlled, which is much faster than mass transport. In addition, the velocity of the reaction is independent on the initial RB-19 concentration and can be represented by the following equation:

$$
c / c_{0}=-k_{\mathrm{app}} t
$$

Where $c$ is the concentration of dye at time $t(\min ), c_{0}$ is the concentration of dye at the initial time, and $k_{\mathrm{app}}\left(\mathrm{mg} \mathrm{dm} \mathrm{min}^{-1}\right)$ is the apparent rate constant.

The value of the apparent rate constant increased from $7.4 \times 10^{-2}$ to $2.7 \mathrm{mg} \mathrm{dm}^{-3} \mathrm{~min}^{-1}$, when the applied current density increased ten-fold from $4 \mathrm{~mA} \mathrm{~cm}^{-2}$ to $41 \mathrm{~mA} \mathrm{~cm}^{-2}$, respectively on a BDD electrode. This represent an increase of around 36 times faster. The comparison of 
the degradation rate at current densities of 21 and $41 \mathrm{~mA} \mathrm{~cm}^{-2}$ shows that the electrodegradation velocity increased around 4 times when the higher current was applied. For 8 and $21 \mathrm{~mA} \mathrm{~cm}^{-2}$, the apparent rate constants were $1.7 \times 10^{-1}$ and $6.6 \times 10^{-1} \mathrm{mg} \mathrm{dm}^{-3} \mathrm{~min}^{-1}$, respectively which is an increase of around 3.8.

In order to verify that the direct degradation of RB-19 by electrochemical oxidation followed a pseudo zero order reaction and the rate is independent on the concentration, the electrochemical degradations were performed at different initial concentrations of RB-19, i.e. 20, 90 and $410 \mathrm{mg} \mathrm{dm}^{-3}$. The curves in Figure $3 \mathrm{~b}$ demonstrate that the concentration decay still follows a linear correlation against time at different RB-19 initial concentrations and with the same slope of around $\approx 3 \mathrm{mg} \mathrm{dm}^{-3} \mathrm{~min}^{-1}$, confirming the kinetic model assumption of a pseudo zero order reaction for the degradation of RB-19 dye. Furthermore, Figure $3 b$ shows that the process was able to remove the dye within 30 minutes when the RB-19 initial concentration was $\leq 90 \mathrm{mg} \mathrm{dm}^{-3}$ but more than 90 minutes when the initial concentration was higher at 410 $\mathrm{mg} \mathrm{dm}{ }^{-3}$. Montanaro and Petrucci ${ }^{[17]}$ also reported a pseudo zero order kinetic reaction model for the electrochemical degradation of RB-19 dye on BDD at an initial concentration of $<150$ $\mathrm{mg} \mathrm{dm}{ }^{-3}$ with a calculated rate constant $k$ of $5.2 \mathrm{mg} \mathrm{dm}^{-3} \mathrm{~s}^{-1}\left(312 \mathrm{mg} \mathrm{dm}^{-3} \mathrm{~min}^{-1}\right)$. The authors do not provide details of the electrochemical cell employed which makes comparisons difficult, however they use $\mathrm{NaCl}$ in an undivided cell. In the presence of chloride, there is electrogeneration of active chlorine and indirect oxidation might have occurred together with the oxidation mediated by hydroxyl radicals produced on the BDD anode surface. These effects could have contributed to the higher rate constant. 
Figure $3 \mathrm{c}$ shows the RB-19 concentration decay as a function of the electrolysis time at different volumetric flow rates in the anodic compartment. The initial concentration was $20 \mathrm{mg}$ $\mathrm{dm}^{-3}$ and the curves highlight the fact that at lower volumetric flow rates the electrodegradation of RB-19 is faster probably due to the longer residence time of the solution in contact with the electrode surface. In addition, this finding confirms that the direct degradation reaction of RB19 on DDB electrodes is an electron transfer controlled process instead of mass transport, since increasing the flow rate decreases the rate of RB-19 removal.

Only few papers have investigated the effect of the volumetric flow rate on the efficiency of electrochemical degradation of organic compounds using BDD. In general, the papers suggest that the oxidation is under mass control, therefore increasing the volumetric flow rate enhanced the mineralization process. Pereira et al. ${ }^{[30]}$ studied the electrochemical degradation of bisphenol A, using a flow reactor with a BDD anode and observed that a higher oxidation rate is link to high volumetric flow rate because enhances the mass transport of the organic species to the electrode surface, where they undergo oxidation mainly by the hydroxyl radicals since a pseudo-first order kinetic behaviour was noted. Elaoud et al. ${ }^{[31]}$ also observed a model of pseudo-first order kinetic for the mineralization of sinapinic acid during electrochemical degradation on a BDD anode and the apparent rate constant increased with volumetric flow rate. Panizza and Cerisola ${ }^{[32]}$ showed that the electro-oxidation of methyl red followed masstransfer-controlled process so the removal rate and current efficiency were enhanced by high volumetric flow rates. The above findings are in contrast to the present paper that report electron transfer process for the removal of RB-19 dye.

Furthermore, Figure 3c shows a linear correlation between the normalized concentration decay of RB-19 and the electrolysis time suggesting a pseudo zero order kinetic model governed 
by equation 15 as suggested by the concentration decay in Figure 3a. The removal of RB-19 occurred faster (short electrolysis time) at lower volumetric flow rates. The dye was totally removed in less than $5 \mathrm{~min}$ at $20 \mathrm{dm}^{3} \mathrm{~h}^{-1}$ with the highest apparent rate constant $\left(4.3 \mathrm{mg} \mathrm{dm}{ }^{-3}\right.$ $\min ^{-1}$ ) see Figure $3 \mathrm{c}$ and $3 \mathrm{~d}$. Figure $3 \mathrm{~d}$ shows the relationship between the apparent rate constant and the volumetric flow rate in the range studied. In general, the rate of RB-19 removal decreased considerable when the volumetric flow rate increased from $20 \mathrm{dm}^{3} \mathrm{~h}^{-1}$ to $80 \mathrm{dm}^{3} \mathrm{~h}^{-1}$ however 40 and $60 \mathrm{dm}^{3} \mathrm{~h}^{-1}$ show similar apparent rate constant. At $100 \mathrm{dm}^{3} \mathrm{~h}^{-1}$ the apparent rate constant value is higher than at $80 \mathrm{dm}^{3} \mathrm{~h}^{-1}$ but it is lower than at $60 \mathrm{dm}^{3} \mathrm{~h}^{-1}$. Therefore, lower volumetric flow rates promoted fast removal of the dye.

TOC removal for the direct degradation process of $20 \mathrm{mg} \mathrm{dm}^{-3}$ of RB-19 dye on BDD at a current density of $41 \mathrm{~mA} \mathrm{~cm}^{-2}$ and $100 \mathrm{dm}^{3} \mathrm{~h}^{-1}$ flow rate was $79 \%$ see Table 1 whereas the decolouration of the same solution (Figure 3a) occurred in $7.5 \mathrm{~min}$. It is more difficult to remove TOC than decolourise the RB-19 dye because during the electrodegradation there is the formation of stable by-products such as amino-anthraquinone, tautomers keto-enolic, hydroquinone and benzoquinone, benzoic acid, and acid aliphatic, such as oxalic acid. ${ }^{[21]}$ Only $27 \%$ of TOC was removed at lower current density $\left(4 \mathrm{~mA} \mathrm{~cm}^{-2}\right)$ during 90 min electrolysis but in general Table 1 shows that TOC removal improves with the current densities and with longer time of electrolyses.

The percentage of TOC removal also improves as the volumetric flow rate decreases as shown in Table 1. High TOC removal (79\%) was achieved at lower electrolysis time (30 min) when the volumetric flow rate was in $20 \mathrm{dm}^{3} \mathrm{~h}^{-1}$, with complete mineralization, $>99 \%$ in 60 min. At lower volumetric flow rates of 40 and $60 \mathrm{dm}^{3} \mathrm{~h}^{-1}$ complete mineralization $>99 \%$, also occurred however it required 90 min of electrolysis. At even higher volumetric flow rates of 80 
or $100 \mathrm{dm}^{3} \mathrm{~h}^{-1}$, mineralization was $79 \%$ in $90 \mathrm{~min}$. Like in the behaviour of the apparent rate constants that increased at lower volumetric flow rates, lower volumetric flow rates promoted high percentage of TOC removal.

Table 1 also shows that as the RB-19 initial concentration increases, it becomes more difficult to promote TOC removal. When the initial concentration of RB-19 was $410 \mathrm{mg} \mathrm{dm}^{-3}$, the TOC removal was near zero before 60 minutes of electrolysis and after 90 minutes of electrolysis, only $7 \%$ of TOC removal was achieved. However, when the initial concentration of RB-19 was 90 and $20 \mathrm{mg} \mathrm{dm}^{-3}, 47 \%$ and $79 \%$ of TOC removal respectively, was achieved after 90 min of electrolysis.

The energy consumption to mineralize RB-19 dye via direct degradation with BDD, shown in Table 1, indicates an increase with the applied current density and with longer electrolysis times. This would be expected due to the parallel unwanted reactions such as the oxygen evolution, equation 9 , that also occur during the mineralization. The energy consumption decreased as the initial concentration of the dye increases for 20 and $90 \mathrm{mg} \mathrm{dm}^{-3}$. For the solution with the highest concentrated of RB-19 (431 mg dm $\left.{ }^{-3}\right)$, the energy consumption was calculated only at 90 minutes of electrolysis since TOC removal was not observed at lower electrolysis time. An increase in the energy consumption can be seen when the volumetric flow rate increases from 20 to $80 \mathrm{dm}^{3} \mathrm{~h}^{-1}$ however comparison of 80 and $100 \mathrm{dm}^{3} \mathrm{~h}^{-1}$ show that for $100 \mathrm{dm}^{3} \mathrm{~h}^{-1}$ the energy consumption values were slightly lower.

High percentage of TOC removal, 79\%, was achieved after 30 minutes at a $20 \mathrm{dm}^{3} \mathrm{~h}^{-1}$ volumetric flow rate with an energy consumption of $183 \mathrm{~kW} \mathrm{~h} \mathrm{~kg}^{-1}$. This finding is important considering that the RB-19 molecule is very stable (Figure $2 \mathrm{~b}$ ) and contrast with other reports 
in the literature where the electrochemical mineralisation of RB-19 on BDD reached $82 \%$ in 120 minutes of electrolysis. ${ }^{[20]}$ Other papers show that the electrochemical/chemical degradation of RB-19 using BDD in the presence of $0.01 \mathrm{~mol} \mathrm{dm}^{-3} \mathrm{of} \mathrm{Cl}^{-}$, requires 210 minutes to achieve total TOC removal. ${ }^{[17]}$ A low percentage of mineralization (65\%) was attained for RB-19 using BDD even in the presence of $34 \times 10^{-3} \mathrm{~mol} \mathrm{dm}^{-3}$ of $\mathrm{NaCl}^{[19]}$ The energy consumption values were not reported by the authors. Vasconcelos et al. ${ }^{[21]}$ reported $37 \%$ of TOC removal of RB-19 dye after 120 min of electrolysis with an energy consumption value of $585 \mathrm{kWh} \mathrm{kg}^{-1}$. Compared to these values the present work reports high percentage of TOC removal with lower energy consumption.

\section{$\underline{3.2 \text { Degradation of RB-19 dye by combined processes }}$}

RB-19 degradation was also evaluated by combination of electrochemical oxidation on $\mathrm{BDD}$ and $\mathrm{H}_{2} \mathrm{O}_{2}$ electrogenerated on $\mathrm{RVC}$ electrode, varying the applied current density $(4,8$, 21 and $41 \mathrm{~mA} \mathrm{~cm}^{-2}$ ) on BDD. In this combined process, the idea is that the additional oxidant agent, $\mathrm{H}_{2} \mathrm{O}_{2}$ generated by the reduction of $\mathrm{O}_{2}$ on the $\mathrm{RVC}$ cathode electrode (equation 1) will contribute to the degradation making it faster. This oxidant species can degrade RB-19 and also to generate hydroxyl radicals (equation 6). Then the RB-19 oxidation during combined process can occur by a concerted interaction with the hydroxyl radicals from BDD and $\mathrm{H}_{2} \mathrm{O}_{2}$, persulfate anion and by direct electron transfer on BDD. However, one disadvantage is that the dye can also be reduced at RVC electrode. The cell configuration in this process consisted on the recirculation of one electrolyte through one flow circuit and one reservoir, the solution entered the catholyte compartment and the exit was connected to the entrance of the anolyte compartment. 
Figure 4a shows the normalized concentration decay of $20 \mathrm{mg} \mathrm{dm}^{-3}$ of RB-19 dye at a volumetric flow rate of $100 \mathrm{dm}^{3} \mathrm{~h}^{-1}$ as a function of the electrolysis time and different applied current densities. The curves show that by increasing the current density the rate of RB-19 removal improved following a pseudo zero order reaction model since a linear relationship between normalized concentration decay and electrolysis time was observed, represented by equation (15). The total removal of RB-19 was achieved in 30 and 20 minutes at current densities of 21 and $41 \mathrm{~mA} \mathrm{~cm}^{-2}$, respectively on combined process. The rate of RB-19 removal is reflected in the values of the apparent rate constant, which increases with the current density (Figure 4b). The highest apparent rate constant rate $\left(9.4 \times 10^{-1} \mathrm{mg} \mathrm{dm}^{-3} \mathrm{~min}^{-1}\right)$ was found at the current density of $41 \mathrm{~mA} \mathrm{~cm}^{-2}$, and is shown in Figure $4 \mathrm{~b}$.

For current densities $\leq 21 \mathrm{~mA} \mathrm{~cm}^{-2}$, the direct degradation (section 3.1) and combined processes show similar apparent rate constant however, for the highest current density applied $\left(41 \mathrm{~mA} \mathrm{~cm}^{-2}\right)$ the direct degradation process shows a higher apparent rate constant than the combined process by approximately three times larger. This finding shows that adding the oxidant species $\left(\mathrm{H}_{2} \mathrm{O}_{2}\right)$ in the configuration suggested in this paper do not seem to improve the rate of RB-19 removal and instead, it is probably better to avoid including a reduction processes in the direct degradation process. Another disadvantage of the use of a single reservoir in the combined process could be that the $\mathrm{H}_{2} \mathrm{O}_{2}$ electrogenerated at the cathode can be oxidized in the anodic compartment (equations 4 and 5). A better way to use hydrogen peroxide as oxidant would be to generate the Fenton reactant using a gas diffusion electrode but this will be subject of another investigation that could improve the combined process proposed here. 
Electro-Fenton (EF) process is an effective method to remove the colour from wastewater containing dyes via the hydroxyl radical $(\bullet \mathrm{OH})$. The Fenton reactant can be obtained from hydrogen peroxide $\left(\mathrm{H}_{2} \mathrm{O}_{2}\right)$ in the presence of $\mathrm{Fe}^{2+}$ ions. RB-19 was removed by EF process using RVC foam unmodified and electrochemical modified in undivided batch electrochemical cell. The modified RVC improved the RB-19 removal reaching $81 \%$ in removal. The TOC removal and energy consumption was not evaluated ${ }^{[33]}$.

In general, the TOC removal improved with the applied current densities and longer electrolysis time, for example a maximum of $72 \%$ in TOC removal was attained at the highest current density of $41 \mathrm{~mA} \mathrm{~cm}{ }^{-2}$ during 90 min of electrolysis. Only $48 \%$ of TOC was removed when a current density of $21 \mathrm{~mA} \mathrm{~cm}^{-2}$ was applied for $90 \mathrm{~min}$ and the lowest TOC removal (20\%) was calculated for $4 \mathrm{~mA} \mathrm{~cm}^{-2}$ in $30 \mathrm{~min}$ of electrolysis, see Figure $4 \mathrm{c}$. The energy consumption in Figure 4d, shows a typical increase of energy consumption as the applied current density increases because extra energy invested is not proportional to the TOC removal probably due to the parasite reactions taking place such as oxygen evolution (equation 9). The highest energy consumption $\left(777 \mathrm{kWh} \mathrm{kg}^{-1}\right)$ was observed at a current density of $41 \mathrm{~mA} \mathrm{~cm} \mathrm{~cm}^{-2}$ at $30 \mathrm{~min}$ of electrolysis. Under these conditions $\left(j=41 \mathrm{~mA} \mathrm{~cm}^{-2}\right.$ and $30 \mathrm{~min}$ of electrolysis), only $19 \%$ of TOC was removed however increasing the electrolysis time to $90 \mathrm{~min}$, the mineralization was $72 \%$ at energy consumption of $612 \mathrm{kWh} \mathrm{kg}^{-1}$.

The comparison between the direct degradation and combined processes shows that the combined process did not improved the RB-19 electrodegradation since lower TOC removal $(72 \%)$ than direct degradation (TOC removal $=79 \%)$ were found, and the energy consumption $\left(612 \mathrm{kWh} \mathrm{kg}^{-1}\right)$ was higher than direct degradation $\left(\mathrm{EC}=561 \mathrm{kWh} \mathrm{kg}^{-1}\right)$ at a current density of $41 \mathrm{~mA} \mathrm{~cm}{ }^{-2}$ for $90 \mathrm{~min}$ of electrolysis at volumetric flow rate of $100 \mathrm{dm}^{3} \mathrm{~h}^{-1}$. In addition, low 
volumetric flow rates in the DD process improved the degradation efficiency. At volumetric flow rates of $20 \mathrm{dm}^{3} \mathrm{~h}^{-1}$, total colour removal was achieved in $5 \mathrm{~min}$ and $80 \%$ TOC was removed in 30 minutes at energy consumption of $183 \mathrm{kWh} \mathrm{kg}^{-1}$ whereas $>99 \%$ TOC removal took 60 minutes with an energy consumption of $279 \mathrm{kWh} \mathrm{kg}^{-1}$. Therefore, it seems that the direct electrochemical oxidation of RB-19 on BDD electrodes and low volumetric flow rates is more efficient method to degrade RB-9 dye based on the conditions studied in this paper.

\section{Conclusions}

(i) The decolourisation and mineralisation of RB-19 dye from aqueous wastewater was studied by two processes: direct degradation using electrochemical oxidation with BDD electrode and combination of processes consisted on $\mathrm{H}_{2} \mathrm{O}_{2}$ electrogenerated on an RVC cathode electrode. Parameters such as current density, volumetric flow rate and initial concentration of dye, play an important role in the process efficiency.

(ii) In general, for the direct degradation process, high current density and longer electrolysis time improved the RB-19 degradation however the energy consumption values also increased. The efficiency of colour and TOC removal strongly depends on the anodic volumetric flow rate.

(iii) Lower volumetric flow rates makes the oxidation more efficient and favours the degradation rates and the process seem to be electron transfer controlled following a pseudo zero order kinetic.

(iv) Thorough the direct degradation process at a current density of $41 \mathrm{~mA} \mathrm{~cm}^{-2}$ and a volumetric flow rate of $20 \mathrm{dm}^{3} \mathrm{~h}^{-1}$, a total colour removal of RB-19 was achieved in less than 5 minutes and $100 \%$ of mineralization was achieved in 60 min, a high TOC removal (79\%) was also observed in 30 min of electrolysis. 
(v) The combined process, did not improve the RB-19 electrodegradation in comparison to the direct degradation process alone since the TOC removal was lower and the energy consumption was higher.

(vi) The results of this paper highlight the fact that higher concentrations of RB-19 are still difficult to mineralise. Further studies using a gas diffusion electrodes to generate hydrogen peroxide combined with an iron salt to generate the Fenton reaction might be useful to mineralise higher concentrations.

\section{Acknowledgements}

The authors wish to acknowledge the financial support provided by the Brazilian funding agencies including São Paulo Research Foundation (FAPESP - grants \#2014/12661-4 and \#2011/15811-9), the Brazilian National Council for Scientific and Technological Development - CNPq (grants no. 465571/2014-0, 301492/2013-1, 302874/2017-8 and 427452/2018-0), the Coordenação de Aperfeiçoamento de Pessoal de Nível Superior (CAPES - Finance Code 001) and the International Office of the University of Southampton through their Southampton-FAPESP scholarship. 


\section{References}

[1] aC.-H. Ho, L. Chen, C.-L. Yang, Environ. Eng. Sci. 2011, 28, 53-61; bJ. E. B. McCallum, S. A. Madison, S. Alkan, R. L. Depinto, R. U. R. Wahl, Environ. Sci. Technol. 2001, 35, 434-434; cM. Siddique, R. Farooq, A. Shaheen, J. Chem. Soc. Pak. 2011, 33, 284-293.

[2] E. J. Weber, V. C. Stickney, Water Res. 1993, 27, 63-67.

[3] J. A. Ramsay, T. Nguyen, Biotechnol. Let. 2002, 24, 1756-1760.

[4] aF. He, W. Hu, Y. Li, Chemosphere 2004, 57, 293-301; bP. V. Nidheesh, R. Gandhimathi, Desalination 2012, 299, 1-15.

[5] aE. Forgacs, T. Cserhati, G. Oros, Environ. Int. 2004, 30, 953-971; bN. Willmott, J. Guthrie, G. Nelson, Biotechnology 1998, 114, 38-41; cP. V. Nidheesh, M. Zhou, M. A. Oturan, Chemosphere 2018, 197, 210-227.

[6] T. Robinson, G. McMullan, R. Marchant, P. Nigam, Bioresour. Technol. 2001, 77, 247-255.

[7] aC. A. Martínez-Huitle, E. Brillas, App. Catal. B: Environ. 2009, 87, 105-145; bE. Brillas, C. A. Martínez-Huitle, Appl. Catal. B: Environ. 2015, 166-167, 603-643; cK. Rajeshwar, J. G. Ibanez, G. M. Swain, J. App. Electrochem. 1994, 24, 1077-1091.

[8] aJ. M. Peralta-Hernández, M. Méndez-Tovar, R. Guerra-Sánchez, C. A. MartínezHuitle, J. L. Nava, Int. J. Electrochem. 2012, 2012, 1-18; bC. A. Martínez-Huitle, E. Brillas, Appl. Catal. B: Environ. 2009, 87, 105-145; cC. A. Martinez-Huitle, S. Ferro, Chem. Soc. Rev. 2006, 35, 1324-1340; dM. Panizza, G. Cerisola, Chem. Rev. 2009, 109, 6541-6569.

[9] aJ. M. Friedrich, C. Ponce-de-León, G. W. Reade, F. C. Walsh, J. Electroanalyt. Chem. 2004, 561, 203-217; bE. Brillas, I. Sirés, M. A. Oturan, Chem. Rev. 2009, 109, 6570-6631.

[10] aA. A. Gallegos, Y. V. García, A. Zamudio, Sol. Energy Mater. Sol. Cells 2005, 88, 157-167; bH. Liu, C. Wang, X. Li, X. Xuan, C. Jiang, H. Cui, Environ. Sci. Technol 2007, 41, 2937-2942.

[11] E. Brillas, R. M. Bastida, E. Llosa, J. Casado, J. Electrochem. Soc. 1995, 142, 17331741.

[12] A. J. Poole, Water Research 2004, 38, 3458-3464.

[13] R. Salazar, E. Brillas, I. Sirés, Appl. Catal., B: Environ. 2012, 115-116, 107-116.

[14] aA. Kraft, Int. J. Electrochem. Sci. 2007, 2, 355-385; bP. A. Michaud, M. Panizza, L. Ouattara, T. Diaco, G. Foti, C. Comninellis, J. App. Electrochem. 2003, 33, 151-154; cB. Marselli, J. Garcia-Gomez, P. A. Michaud, M. A. Rodrigo, C. Comninellis, J. Electrochem. Soc. 2003, 150, D79-D83.

[15] J. Davis, J. C. Baygents, J. Farrell, Electrochim. Acta 2014, 150, 68-74.

[16] M. Siddique, R. Farooq, A. Shaheen, Journal of the Chemical Society of Pakistan 2011, 33, 284-293.

[17] D. Montanaro, E. Petrucci, Chem. Eng. J. 2009, 153, 138-144.

[18] E. Petrucci, D. Montanaro, Chem. Eng. J. 2011, 174, 612-618.

[19] A. H. Degaki, G. F. Pereira, R. C. Rocha-Filho, N. Bocchi, S. R. Biaggio, Electrocatalysis 2014, 5, 8-15.

[20] L. S. Andrade, L. A. Ruotolo, R. C. Rocha-Filho, N. Bocchi, S. R. Biaggio, J. Iniesta, V. Garcia-Garcia, V. Montiel, Chemosphere 2007, 66, 2035-2043.

[21] V. M. Vasconcelos, F. L. Migliorini, J. R. Steter, M. R. Baldan, N. G. Ferreira, M. R. de Vasconcelos Lanza, Journal of Environmental Chemical Engineering 2016, 4, 3900-3909. 
[22] C. d. N. Brito, D. R. da Silva, S. Garcia-Segura, D. C. de Moura, C. A. MartínezHuitle, Journal of The Electrochemical Society 2015, 163, E62-E69.

[23] R. M. Farinos, L. A. M. Ruotolo, Electrochimica Acta 2017, 224, 32-39.

[24] C. Ponce de Leon, D. Pletcher, J. Appl. Electrochem. 1995, 307-314.

[25] J. M. Friedrich, C. Ponce-de-León, G. W. Reade, F. C. Walsh, Journal of Electroanalytical Chemistry 2004, 561, 203-217.

[26] V. M. Vasconcelos, C. Ponce-de-León, J. L. Nava, M. R. V. Lanza, Journal of Electroanalytical Chemistry 2016, 765, 179-187

[27] M. Panizza, G. Cerisola, Ind. Eng. Chem. Res. 2008, 47, 6816-6820.

[28] S. I. Bailey, I. M. Ritchie, Electrochim. Acta 1985, 30, 3-12.

[29] aJ. H. Ramirez, C. A. Costa, L. M. Madeira, Catal. Today 2005, 107-108, 68-76; bW. Feng, D. Nansheng, H. Helin, Chemosphere 2000, 41, 1233-1238; cM. Stylidi, Appl. Catal. B: Environ. 2004, 47, 189-201; dC. Galindo, P. Jacques, A. Kalt, J. Photochem. Photobiol. 2000, 130, 35-47; eN. M. Mahmoodi, M. Arami, N. Y. Limaee, N. S. Tabrizi, Chem. Eng. J. 2005, 112, 191-196.

[30] G. F. Pereira, R. C. Rocha-Filho, N. Bocchi, S. R. Biaggio, Chemical Engineering Journal 2012, 198-199, 282-288.

[31] S. C. Elaoud, M. Panizza, G. Cerisola, T. Mhiri, Desalination 2011, 272, 148-153.

[32] M. Panizza, G. Cerisola, Ind. Eng. Chem. Res. 2008, 47, 6816-6820.

[33] W. Zhou, Y. Ding, J. Gao, K. Kou, Y. Wang, X. Meng, S. Wu, Y. Qin, Environmental Science and Pollution Research 2018, 25, 6015-6025. 


\section{Figures caption}

Figure 1: Scheme of flow during (a) direct degradation process. (b) combined process.

Figure 2: (a) Color removal of solutions containing $20 \mathrm{mg} \mathrm{dm}^{-3}$ of RB-19 in $0.5 \mathrm{~mol} \mathrm{dm}$ of $\mathrm{Na}_{2} \mathrm{SO}_{4}$ at ambient temperature $\left(23^{\circ} \mathrm{C}\right)$ after $(\square) 30$ and $(\square) 90$ min of electrolysis in function of current density. (b) Spectra of solutions containing RB-19 in function of electrolysis time using BDD applying $41 \mathrm{~mA} \mathrm{~cm}^{-2}$. The volumetric flow rate was 100 $\mathrm{dm}^{3} \mathrm{~h}^{-1}$.

Figure 3: (a) Normalized decay in concentration of RB-19 in function of time of electrolysis

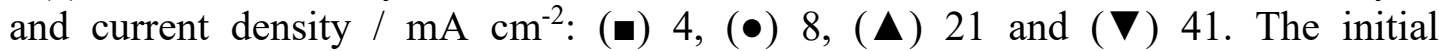
concentration of RB-19 dye was $20 \mathrm{mg} \mathrm{dm}^{-3}$ at a flow rate of $100 \mathrm{dm}^{3} \mathrm{~h}^{-1}$.(b) Decay in concentration of RB-19 in function of time of electrolysis and RB-19 initial


a flow rate of $100 \mathrm{dm}^{3} \mathrm{~h}^{-1}$. (c) Normalized decay in concentration of RB-19 in function of time of electrolysis and flow in anode part of reactor/ $\mathrm{dm}^{3} \mathrm{~h}^{-1}:(-) 20,(\circ) 40,(\Delta) 60$, () 80 and (+) 100 applying $41 \mathrm{~mA} \mathrm{~cm}^{-2}$. The initial concentration of RB-19 dye was $20 \mathrm{mg} \mathrm{dm}^{-3}$. (d) Apparent rate constant in function of flow in anode part of reactor. The electrolyte support was $0.5 \mathrm{~mol} \mathrm{dm}^{-3}$ of $\mathrm{Na}_{2} \mathrm{SO}_{4}$ at ambient temperature $\left(23^{\circ} \mathrm{C}\right)$. The initial concentration of RB-19 dye was $20 \mathrm{mg} \mathrm{dm}^{-3}$.

Figure 4: (a) Normalized decay in concentration of RB-19, (b) apparent rate constant, (c) TOC removal and (d) energy consumption (EC) values in RB-19 degradation by combined processes using BDD and RVC electrodes in function of electrolysis time and current density / $\mathrm{mA} \mathrm{cm}^{-2}:(\square) 4,(\circ) 8,(\Delta) 21(\diamond) 41$. The electrolyte support was $0.5 \mathrm{~mol} \mathrm{dm}^{-}$ ${ }^{3}$ of $\mathrm{Na}_{2} \mathrm{SO}_{4}$ at ambient temperature $\left(23{ }^{\circ} \mathrm{C}\right)$ at flow of $100 \mathrm{dm}^{3} \mathrm{~h}^{-1}$. The initial concentration of RB-19 dye was $20 \mathrm{mg} \mathrm{dm}^{-3}$. 


\section{Figures}

a)



b)



Figure 1 
a)



b)

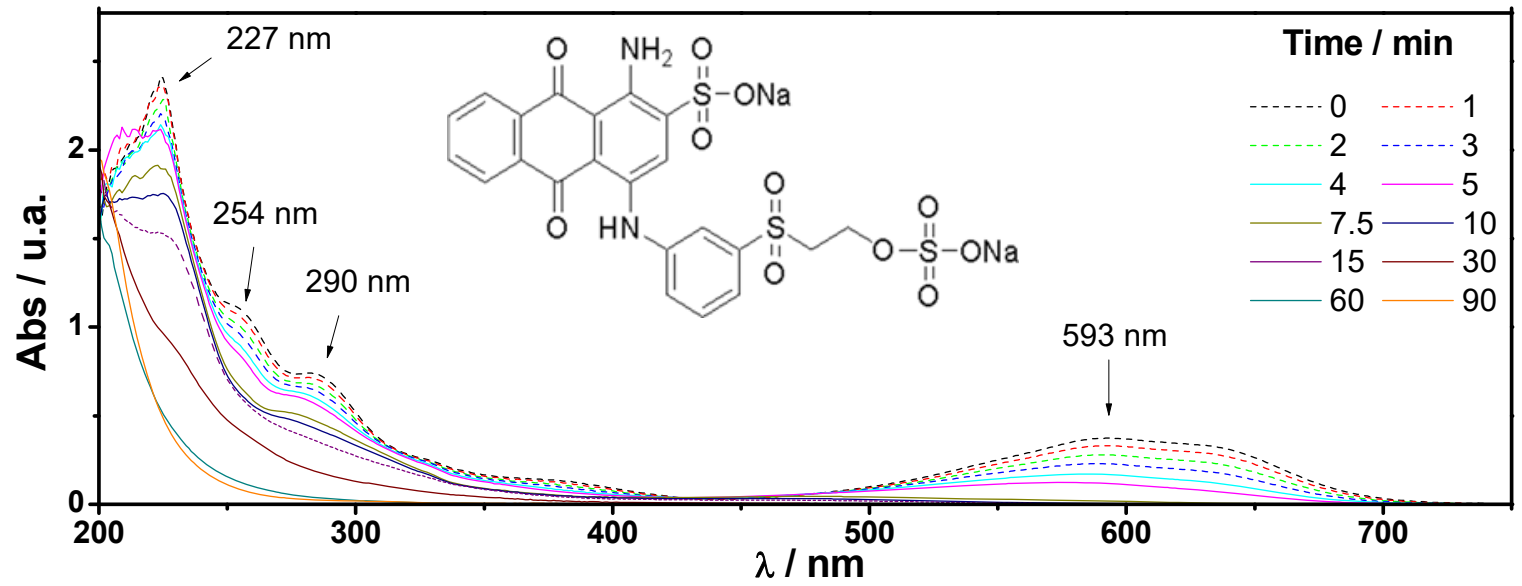

Figure 2 

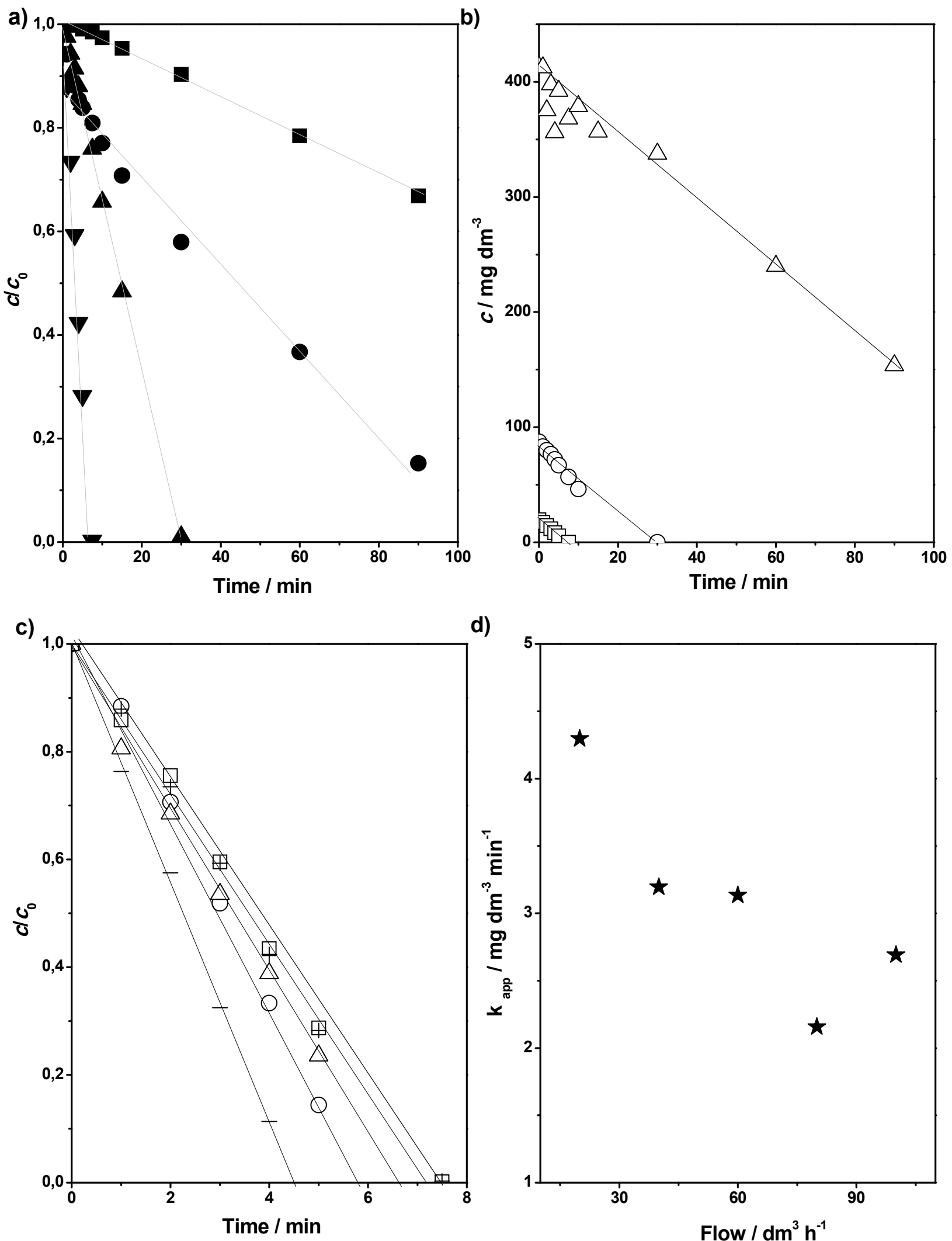

Figure 3 
a)


b)

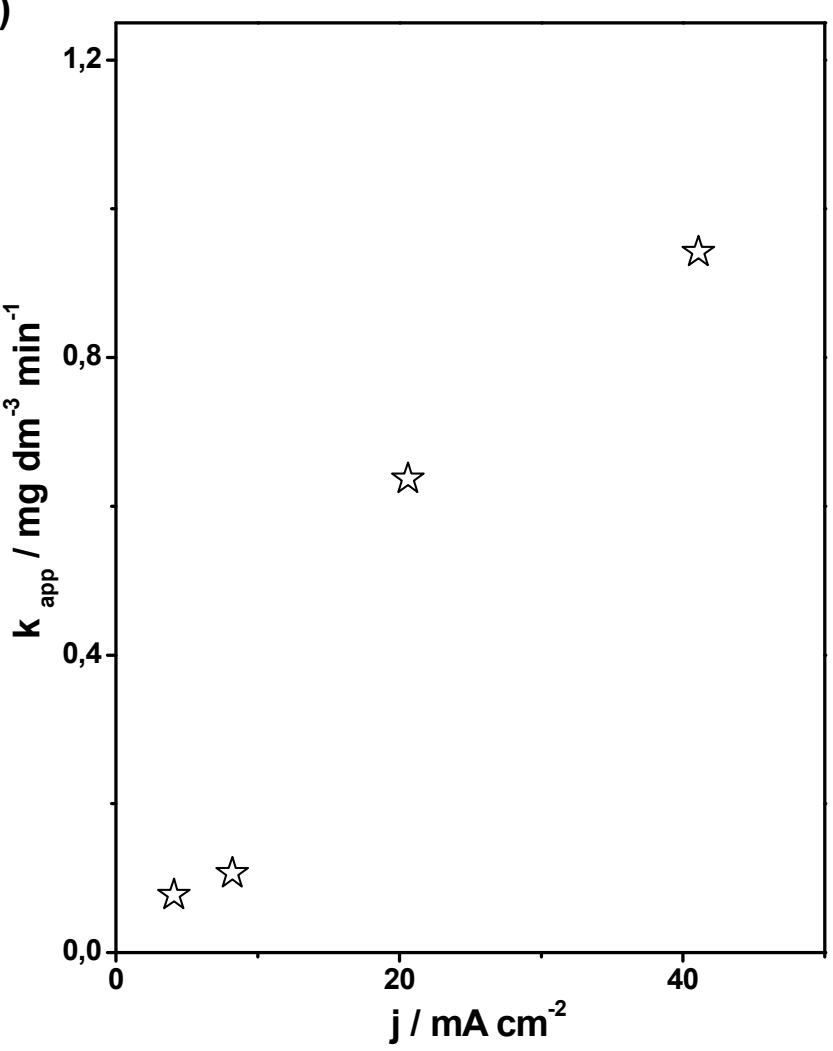

d)

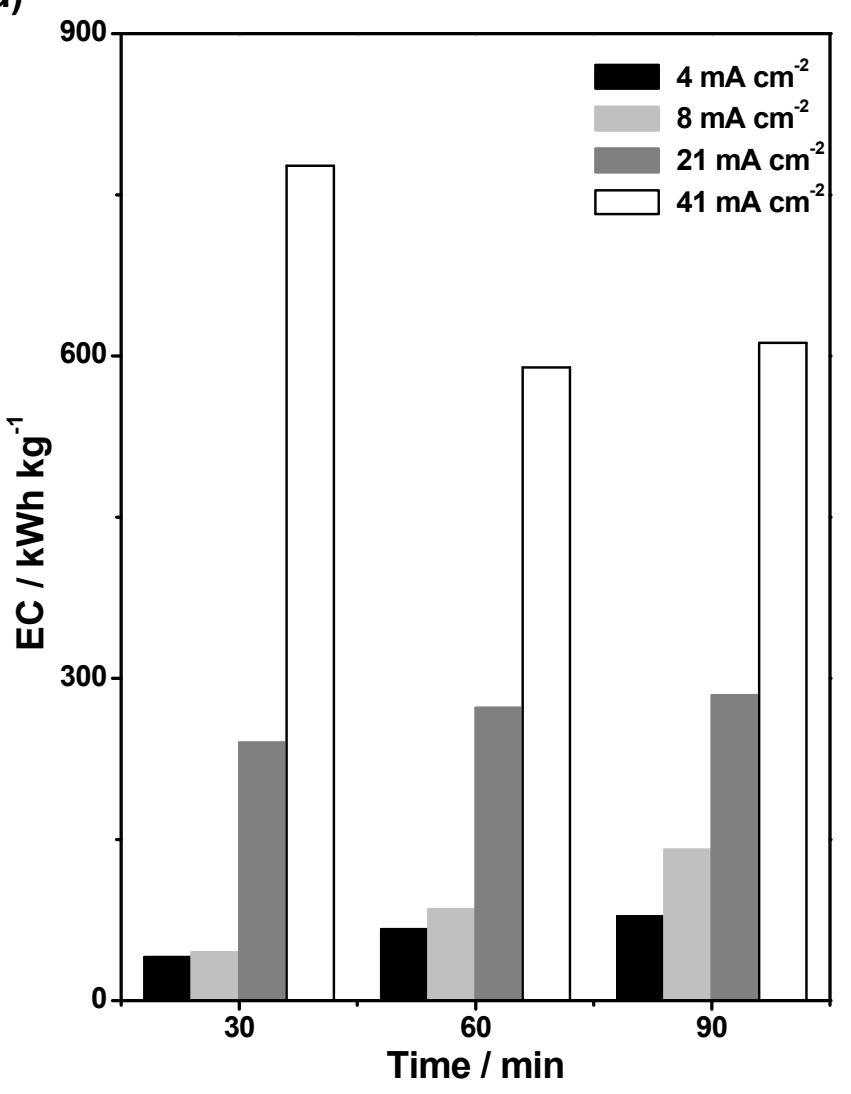

Figure 4 
Table 1

\begin{tabular}{|c|c|c|c|c|c|c|c|}
\hline \multirow{2}{*}{\multicolumn{2}{|c|}{ Direct degradation (BDD) }} & \multicolumn{3}{|c|}{ TOC removal / \% } & \multicolumn{3}{|c|}{ EC / kWh kg-1 } \\
\hline & & $30 \mathrm{~min}$ & $60 \mathrm{~min}$ & $90 \mathrm{~min}$ & $30 \mathrm{~min}$ & $60 \mathrm{~min}$ & $90 \mathrm{~min}$ \\
\hline \multirow{4}{*}{ 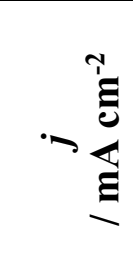 } & 4 & 10 & 18 & 27 & 100 & 107 & 101 \\
\hline & 8 & 23 & 30 & 40 & 68 & 100 & 109 \\
\hline & 21 & 23 & 30 & 37 & 221 & 326 & 377 \\
\hline & 41 & 20 & 55 & 79 & 753 & 511 & 561 \\
\hline \multirow{5}{*}{ 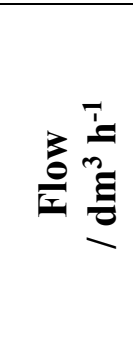 } & 20 & 79 & 100 & 100 & 183 & 279 & 436 \\
\hline & 40 & 65 & 97 & 100 & 230 & 296 & 449 \\
\hline & 60 & 65 & 90 & 100 & 234 & 321 & 453 \\
\hline & 80 & 19 & 52 & 79 & 758 & 543 & 557 \\
\hline & 100 & 20 & 55 & 79 & 753 & 511 & 561 \\
\hline \multirow{3}{*}{ 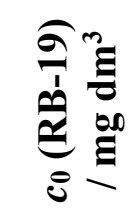 } & 20 & 20 & 55 & 79 & 753 & 511 & 561 \\
\hline & 90 & 14 & 29 & 47 & 258 & 230 & 192 \\
\hline & 410 & $*$ & $*$ & 7 & $* *$ & $* *$ & 404 \\
\hline
\end{tabular}

* Not detected

** Not possible to calculate

Table 1 TOC removal and energy consumption (EC) values as a function of electrolysis time, current density (at flow rate of $100 \mathrm{dm}^{3} \mathrm{~h}^{-1}$ and initial concentration of RB19 dye of $20 \mathrm{mg} \mathrm{dm}^{-3}$ ), flow rate in the anode part of reactor (at current density of $41 \mathrm{~mA} \mathrm{~cm}^{-2}$ and initial concentration of RB-19 dye of $20 \mathrm{mg} \mathrm{dm}^{-3}$ ) and RB19 initial concentration (at current density of $41 \mathrm{~mA} \mathrm{~cm}^{-2}$ and flow rate of 100 $\left.\mathrm{dm}^{3} \mathrm{~h}^{-1}\right)$. The electrolyte support was $0.5 \mathrm{~mol} \mathrm{dm}^{-3}$ of $\mathrm{Na}_{2} \mathrm{SO}_{4}$ at ambient temperature $\left(23^{\circ} \mathrm{C}\right)$. 